\title{
Posterior reversible encephalopathy syndrome during treatment with tocilizumab in juvenile idiopathic arthritis
}

Síndrome da encefalopatia posterior reversível após tratamento com tocilizumab em paciente com artrite idiopática juvenil

Marcos Rosa Júnior', Érico Induzzi Borges², Ana Paula Alves Fonseca², Juliana Largura Fiorot², Lídia Balarini, Valéria Valim ${ }^{3}$

A 17-year-old man with normal blood pressure presented with acute bilateral blindness, and retro-orbital pain two days after treatment with tocilizumab (TCZ) for juvenile idiopathic arthritis. The diagnosis was posterior reversible encephalopathy syndrome (PRES), made after clinical examination and MRI (Figure).
Tocilizumab was discontinued and the patient partially improved. To the best of our knowledge, there are no reports of this association (PRES and TCZ) in PubMed. This manuscript describes a new association between TCZ and PRES based on imaging findings, in which the patient presented with more severe imaging findings and did not have complete recovery of the symptoms ${ }^{1,2,3}$.
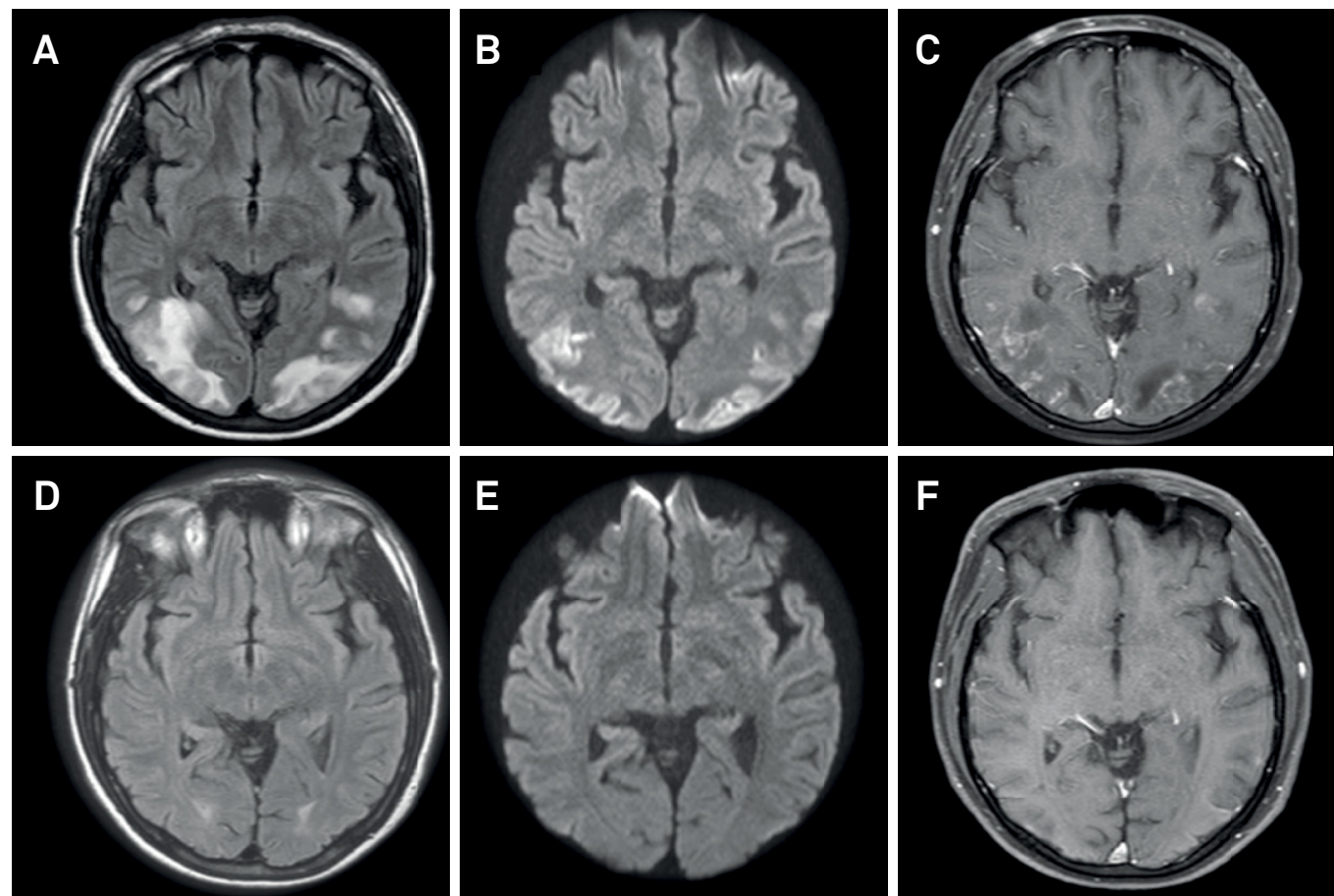

Figure. MRI showed cortical and subcortical FLAIR hyperintense signals involving the occipital lobes (A), with restricted diffusion (B) and contrast enhancement (C). The findings of diffusion restriction and contrast enhancement are more severe imaging findings and are described as factors of a worse prognosis and partial recovery in PRES. After TCZ withdrawal, the patient's imaging findings improved (D, E, and F), with partial recovery of the visual symptoms.

\footnotetext{
'Universidade Federal do Espírito Santo, Hospital Universitário Cassiano Antônio de Moraes, Departamento de Neurorradiologia, Vitória ES, Brasil; ${ }^{2}$ Universidade Federal do Espírito Santo, Vitória ES, Brasil;

${ }^{3}$ Universidade Federal do Espírito Santo, Hospital Universitário Cassiano Antônio de Moraes, Departamento de Reumatologia, Vitória ES, Brasil. Correspondence: Marcos Rosa Júnior; Avenida Marechal Campos, 1355, Maruípe; 29043-900 Vitória ES, Brasil; E-mail: marcosrosajr@hotmail.com Conflict of interest: There is no conflict of interest to declare.

Received 04 March 2018; Received in final form 14 May 2018; Accepted 16 May 2018.
} 


\section{References}

1. Yokota S, Tanaka T, Kishimoto T. Efficacy, safety and tolerability of tocilizumab in patients with systemic juvenile idiopathic arthritis. Ther Adv Musculoskelet Dis. 2012;4(6):387-397. https://doi.org/10.1177/1759720X12455960

2. Dueckers G, Guellac N, Arbogast M, Dannecker G, Foeldvari I, Frosch $\mathrm{M}$ et al. Evidence and consensus based GKJR guidelines for the treatment of juvenile idiopathic arthritis. Clin Immunol. 2012;142(2):176-193. https://doi.org/10.1016/j.clim.2011.10.003

3. Hinchey J, Chaves C, Appignani B, Breen J, Pao L, Wang

A et al. A reversible posterior leukoencephalopathy syndrome. N Engl J Med. 1996;334(8):494-500. https://doi.org/10.1056/NEJM199602223340803 